\title{
HISTORY of POLITICAL ECONOMY
}

\author{
DUKE UNIVERSITY PRESS
}

\section{The Eastern Christian Fathers (A.D. 350-400) on the Redistribution of Wealth}

\section{Anastassios D. Karayiannis}

In the second half of the fourth century A.D., the Eastern Christian Fathers developed some interesting economic ideas and suggestions, scattered throughout their religious texts, the majority of which focused on solving the problem of the extreme maldistribution of wealth. Though they blamed the institutional malfunction of the economy for this problem, they did not develop drastic measures for a revolutionary reconstruction to transform the existing institutions, or turn against the market norms. Instead, they tried to convince individuals to increase their altruistic behavior and to prove that such behavior would increase the general welfare. The Fathers, by incorporating ethical judgments in their economics ideas, developed commandments, propositions, and exhortations, justified on religious and economic grounds, in order to reduce the consequences of the unequal distribution of wealth. Their aim was to prove that such a distribution was contrary not only to Christian teachings but also to the economic interests of both rich and poor citizens.

These various ideas, arguments, and suggestions are discussed in the following manner. Section 1 exposes the Fathers' views on the

Page 39

causes and effects of the extremely unequal distribution of wealth. Section 2 analyzes their propositions to eliminate this maldistribution of wealth. Section 3 discusses their justifications for the redistribution of wealth from an ethical, religious, and economic standpoint. Finally, section 4 considers their solutions to the maldistribution of wealth in relation to their economic ideas.

The present paper does not consider relevant views and arguments expressed by other religious authors of the previous or the same age (i.e., the Western Fathers). Further, the development of the ideas and views stated are not traced or compared with those expressed by subsequent religious authors. The analysis is primarily based on and limited to the views developed by the Eastern Fathers, such as Cyril of Jerusalem, Nemesius of Emessa, Titus of Bostra, Basil the Great, John Chrysostom, and Gregory of Nazianzus. However, the ideas of some important writers of the previous century, such as Clement of Alexandria, are also examined, in order to illustrate any influence or contradiction.

\section{Maldistribution of Wealth: Causes and Effects}

The Fathers recognized three classes of significant causes that produced an unequal distribution of wealth: (1) the behavior of individuals; (2) the accumulation of wealth and its use; and (3) the structure and function of the economy. Regarding the behavioral causes, they discussed the effects of the maximizing behavior of individuals and their attitude toward the estimation, use, and accumulation of wealth. 
Then they dealt with the accumulation of wealth in terms of fair or unfair economic actions. In addition, they recognized the following causes of the unequal distribution of wealth that are generated by the structure and function of the economy: $(a)$ the scarcity of goods; (b) the function of money; (c) the existence of usury; $(d)$ the position of laborers; and $(e)$ the structure and function of agricultural production. For the Fathers, the unequal distribution of wealth resulted from a class-structured society, where poverty prevailed among the masses while the minority lived luxuriously. The Fathers considered this dual consumption economy an indication of an unfair and inhumane society.

Page 40

\subsection{Economic Behavior}

John Chrysostom, the most productive writer of all the Fathers at this time, argued that when the motive of self-interest and the maximizing behavior of individuals is focused on material aspirations, that is, on "indolence, material comfort, and pleasure" (Chrysostom 1962-75, vol. 42, 87D), injustice, misery, and ethical corruption will prevail in society. ${ }^{1}$ This happens "because the person who yearns for money will cause his neighbors infinite evil" (vol. 75, homily 87.3), and "the source of all evil is excess and the desire to have more than we need" vol. 47, 380B). Further, "When one thinks only about money . . . in-terest, loans, profit, and base commerce [then] he will betray human nobility and freedom" (vol. 64, 263A-B), and for that reason "I advise you not to seek after wealth" (vol. 76, homily 13.3). ${ }^{2}$

The maximizing behavior of individuals toward material things af-fects their attitude regarding the use and accumulation of wealth. The fathers strongly emphasized the idea that material wealth is only a means to fulfill human needs and not an end in itself (Houmanidis [1972] 1979, 42), and must be evaluated in relation to the norms of a virtuous life as described in the teachings of the ancient Greek philos-ophers and by Jesus Christ. However, they observed that in reality most people accumulate wealth for its own sake (see Clement of Alex-andria 1956a, 3.6) and to increase their social status and power. They considered this behavior to be irrational and outside truly valuable hu-man aspirations and achievements. In order to prove that this pursuit

1. The ancient Greek philosopher Plato developed the same argument against the maxilizing behavior of individuals toward material things (see Karayiannis 1990, 67). Although this paper does not intend to extract the originality of the discussed ideas and to trace their development in the various religious and philosophical writings of antiquity, it must be mentioned that many economic ideas and views developed by the ancient Greek philosophers were adopted by the Fathers of the Eastern church, who derived their views and arguments from the Old and New Testaments. However, their Hellenic approach to some of the eco-nomic subjects is justified because of their Greek educational and philosophical background (see Vallianos 1979, 43-57; Geanakoplos 1980, 94-102). Concerning this approach, Adeney notes "that the orthodox Greek theologians were Platonic in their spirit and thought" ([1908] 1965, 75); and Gordon comments that the Eastern Fathers were "interpreting the Scriptures with minds heavily conditioned by Hellenistic philosophy" $(1975,91)$.

2.The translation of the quoted statements of the Fathers are mine except where otherwise noted. 
was a trivial one, they contended that the amount of material wealth is subjectively and not objectively estimated. ${ }^{3}$

More specifically, Basil the Great argued that the rich who had an insatiable desire for wealth, that is, who considered wealth as an end in itself, always felt themselves poor: "Your insatiable desire makes you poor" (Basil 1976, vol. 11, 56C). Thus he noticed that the rich, by their own psychology, subjected themselves to scarcity. Basil describes in the following words the psychology of the rich class regarding wealth-a description showing that he, according to Gordon $(1989,113)$, "is no stranger to what, in more recent times, has been termed, the Duesenberry effect":

You say you are poor, and I agree with you; for anyone who needs a great many things is poor, and you have a great many needs because your desires are many and insatiable. ... When they [i.e., the rich] ought to rejoice and give thanks that they are wealthier than so many others, they are troubled and sad because some one is richer than they. When they have equaled his wealth at once they try to reach the fortune of one still richer. When they attain a wealth equal to his, they transfer this emulation to a third. (Gordon 1989, 113; emphasis added)

Chrysostom, similarly emphasizing that the "desire for money is neither natural nor necessary, but useless" (1962-75, vol. 75, homily 74.3), maintained that the behavior and the subjective estimation of individuals were the main factors that determined the amount of wealth or the rate of scarcity:

$\mathrm{He}$ is not the rich who is surrounded by many possessions, but he who does not need many possessions; and he is not poor who possesses nothing, but he who requires many things. We ought to consider this to be the distinction between poverty and wealth. . . . For by the condition of our mind, not by the quantity of our material wealth, should it be our custom to distinguish between poverty and affluence. . . We can never think those wealthy who are perpetually desiring and thirsting for other people's possessions, not even if they enjoy a certain kind of abundance ... he who does not desire

3.Chrysostom regarded material wealth as consisting of goods and precious metals that have an exchange value (1962-75, vol. 49, 487E, 506B-C)-something that Clement of Alexandria had already noticed (1956c, 359, 10-20).

Page 42

other people's possessions, but is willing to be satisfied with his own, is the wealthier of all. (Chrysostom 1869, 727B, D, 39-40).

\subsection{Accumulation and Use of Wealth}

Regarding motives in accumulating wealth, the Fathers approached he issue from a religious and economic point of view. In general, they turned against the accumulation of wealth because they judged that it was not treated properly. More specifically, by ignoring the posi-tive economic effects produced by accumulation and investment activity, the Fathers discussed its consequences in relation to: (a) the way that this accumulation had taken place; $(b)$ the avarice which characterized most of the rich; and (c) the rational or irrational use of wealth.

Regarding the first argument against the accumulation of wealth, that is, when it is gathered through unfair economic actions, Chrysos-tom condemns this procedure or 
"the rapaciousness which slowly kills the poor man" (1962-75, vol. 67, 536C; see also vol. 46, 335B-C; vol. 49, 110D), as do Nemesius of Emessa $(1968,801)$ and Gregory of Nazianzus also (1977, vol. 5, 34.15-20, homily 14). Basil also turned against this tactic when he noticed one case where the actions of producers and merchants could cause unfairness in the market and increase unequal distribution. He blamed-as did Gregory of Nazianzus (1977, vol. 5, 19.5-10, homily 16)-those merchants who in times of short supply hoard goods in order to increase their prices. ${ }^{4}$ As Basil says, "Do not wait for a shortage of wheat to open your granaries. ... Do not acquire gold through famine nor use general poverty to amass wealth. Do not become a profiteer of human misfortune" (1976, vol. 11,46B-C).

The same attitude toward trade was also shown by Chrysostom (see also Ohrenstein 1970, 31), who warned producers not to practice the retail merchant's activities because that was a source of sin and unfairness: "So let us examine the class of professionals and artisans. Truly they are viewed, more than any other, as living by their hard labor and

4.However, Basil recognized the usefulness of trade activity, when in a statement in his Hexaemeron (4.36) he mentioned that by sea-trade knowledge is increased, and the products are distributed according to their surplus and shortage between different countries - an argument on behalf of trade developed by Aristotle (Karayiannis 1990, 9 n. 7; 1992, 69) and Basil's teacher, the Greek philosopher Libanius (Viner 1978, $37)$.

Page 43

sweat. But when they do not pay the proper attention to themselves, their work produces a great deal of evil for themselves. Because injustice, which arises from buying and selling, is introduced into work which requires fair labor" (1962-75, vol. 67, 613D; emphasis added).

Regarding the relationship between avaricious behavior and the accumulation process, the Fathers developed the following arguments based upon ethical, social, and economic grounds. Nemesius of Emessa $(1968,800-1)$ argued that man must pursue a virtuous life and not wealth, which corrupts. Titus of Bostra $(1959,3.9)$ also stated that the motive for the accumulation of wealth is mostly accompanied by avaricious behavior, which causes injustice and sin. The same argument against the accumulation of wealth was also put forward by Basil (1972b, vol. 2, 42.25-35), who added that this process shows a "kind of idolatry of money" (53.10-15). ${ }^{5}$ In his "Homily to the Rich," Basil asked, "When will you use what you have acquired at present? When will you enjoy it, since you are always constrained by the toil of making new acquisitions?" (Gordon 1989, 113). ${ }^{6}$

Moreover, Basil maintained that the passion for unlimited wealth has its roots in the devil and dismissed the vulgar view that the rich gain glory among their fellow citizens (1976, vol. 12, 20, 157A-B). On the contrary, he maintained, as the ancient Greek philosophers had done (see Karayiannis 1988, 382; 1990, 27-28), that only wisdom and prudence give glory to men (157E). Chrysostom similarly, through numerous references to the writings of the Socratic philosophers, offered the same ethical and social estimation of wealth, emphasizing that wealth must not be treated as a source of glory, which is only a product of virtue (1962-75, vol. 13, 65-67; vol. 16, $31 \mathrm{~A})^{7}$

Another negative social effect produced by the accumulation of wealth, for Basil (1976, vol. 11, 59B) as well as for Gregory of Nazianzus (1977, vol. 5, 25.5-20), was 
its role in causing wars,

5.Similarly, Clement of Alexandria characterized avarice as the "citadel of malice" (1956a, 2.3)

6.Gordon comments $(1989,113)$ that "Basil, like Karl Marx, also remarks on the peculiar lack of attachment to personal use-values of his contemporary rentier capitalists."

7.Augustine (1954-56, 5.18) expressed a similar view regarding the estimation of wealth in terms of glory. He also turned against the "idolatry of money," noticing as Plato had previously done (see Karayiannis 1990, 27) - that in accordance with the old religion the goddess of wealth, Pecunia, stayed in darkness while the goddess Minerva stayed in light (1954-56,7.3).

Page 44

injustice, slavery, poverty, and conflicts-an argument against the accumulation of wealth that had been developed earlier by Plato (Karayiannis 1990, 28). Basil so opposed the accumulation of wealth, because of his aforementioned arguments and his monastic life (Spent-zas [1969] 1984, 116), that he rejected "as an adequate motive for accumulation the desire to provide for children or for old age" (Viner 1978, 22).

Chrysostom was not so hostile to the accumulation of wealth if it was consumed rationally, that is, in the consumption of necessary goods and in charity. On this ground he appreciated the "economizing" activity and dismissed the avaricious one.

Economy itself is good in the sense that the perfect economist would spend according to need and not stupidly and wastefully. But avarice is not the same. Because the one [i.e., the economist] always spends in a proper fashion while the other [i.e., the avaricious] will not touch his money, even when need unavoidably demands he do so. (1962-75, vol. 79, homily 48.4)

Wealth is not forbidden if it be used for that which is necessary. ... A covetous man is one thing, and a rich man is another thing. The covetous man is not rich; he is in want of many things, and while he needs many things, he can never be rich. The covetous man is a keeper, not a master, of wealth; a slave not a lord. For he would sooner give any one a portion of his flesh, than his buried gold. (Chrysostom 1842, 41).

Chrysostom does not turn against avarice only because such behavior is unnatural (1962-75, vol. 68, 770A), or because it produces insatiability for material goods (vol. 44, 202D; vol. 68, 771B), or encourages unfair transactions (vol. 54, 94D; vol. 73, homily 40.4), but also because it produces a negative economic effect. Chrysostom, like Basil, emphasized that the idle hoarding of material goods or money diminishes the volume of supply and the circulation of goods and thus poverty is increased. As Chrysostom stated, "Wheat when it is kept in granaries to be eaten by worms becomes worthless and spoils, while when it is scattered over the fields it multiplies and is renewed" (vol. 2, 530B; see also vol. 10, 388C). On the same ground Basil developed a macroeconomic argument against avaricious behavior and hoarding. He recognized that stagnant wealth diminished in-

Page 45

vestment activity and thus the profits of the investors and the benefits to the public (Constantelos 1968, 22-23; 1981, 84; Gordon 1989, 115). He noticed that "static wealth is useless; it must circulate to be of social benefit and productive" (1976, vol. 


\section{$11,48 \mathrm{~A})$.}

Another cause explaining Chrysostom's opposition to the motive for the accumulation of wealth is related to its direct psychological consequences. According to Chrysostom, the accumulative activity of individuals is accompanied by cares, risks, troubles; things that shrink human nobleness and freedom (1962-75, vol. 31, 747A; vol. 35, 187B-C; vol. 49, 497E; vol. 64, 263A-B)—an observation that was also put forward by Titus of Bostra $(1959,2.8)$. Thus, Chrysostom questioned why people are inclined toward the accumulation of material goods, which results in so many negative psychological consequences for them (1962-75, vol. 63, 138B).

Regarding the third argument against the accumulation of wealth, the Fathers discussed the rational or irrational use of wealth, attempting to provide ethical foundations for its use - the same approach used by the Socratic philosophers, and particularly Plato (Karayiannis 1990, 27-28). Titus of Bostra (1959, 2.7-8), arguing against the beliefs of the heretic Manichaeans, stated that the existence of wealth and poverty did not prove any disorder in society. On the contrary, he noted that such a situation allowed the poor to show their ethical strength, and the rich to show their humanity by sharing their possessions. Chrysostom, on the other hand, accepted the accumulation of wealth that accrued by fair ethical and economic actions-as in the case of the saving of a small surplus (1962-75, vol. 11, 34B) -and was used rationally. He explained his position in regard to the accumulation and use of wealth as follows:

I am often reproved for always attacking the rich. Of course I do, for they are always attacking the poor-and anyhow, I never attack the rich as such but only those who misuse their wealth. I keep on pointing out that I accuse not the rich but the rapacious: wealth is one thing, covetousness quite another. Learn to distinguish things and not to confuse together what ought not to be confused. (Att-water 1959, 66; emphasis added; see also Chrysostom 1962-75, vol. 74, homily 64.4)

Further, Chrysostom considered that the only rational use of wealth is that of not hoarding (1962-75, vol. 64, 273C, 297C) but spending

Page 46

on necessary goods and in almsgiving ${ }^{8}$ (vol. 55, 146C) - an argument also raised previously by Clement of Alexandria (1956c, 365, 5-10; 367, 10-20), and Basil, who while not condemning wealth per se (Christou 1975, 126-27; Constantelos 1981, 84) commented: "Those who think logically and wisely will see that wealth is not to be used for pleasure, but for proper management and to assist those in need" (Basil 1976, vol. 11,54E).

However, the Fathers believed that most of the rich did not use their wealth rationally. They tried to convince them by exhortations and advice to share it with the poor, namely, to use it rationally. Chrysostom emphasized that "it is inhuman to enjoy your fortune on your own" (1962-75, vol. 67, 536C; see also vol. 10, 388C; vol. 66, 509A), while Gregory of Nazianzus warned "do not love wealth if you do not use it to offer help to the poor" (1977, vol. 5, 7.5-7, homily 44).

\subsection{The Structure and the Function of Economy}

In addition to the above considerations regarding the causes producing a maldistribution of wealth, the Fathers developed more economic reasons generated by the structure and function of the economy.

First, the Christian Fathers of the Eastern church, specifically Chrysostom (1962- 
75, vol. 63, 69B) and Gregory of Nazianzus (1977, vol. 5, 11.15-20, homily 19), stressed that the unequal distribution of income and wealth was unavoidable because, given the volume of production, the richness of some caused the poverty of others. On the other hand, they recognized that with the scarcity of production in relation to multiple needs, the existence of accumulation and the consumption of luxury goods will cause individuals to experience unequal living standards. Because of this, Basil (1976, vol. 11, 49E) stated that when all individuals consumed only necessary goods and shared their surplus with others, the problem of poverty could be eliminated.

8. According to Chrysostom, "True wealth and unspent fortune consist, on the one hand, in seeking what we need, and on the other in disposing as we must our surplus" (1962-75, vol. 47, 382A; see also vol. 55, 146C), that is, "by not expending them [i.e., our surplus] on superfluous wants, nor for our own needs only, but by imparting them also to the poor" $(1869,52)$. Similarly, Cyril of Jerusalem in a statement from his Catechisms emphasized that "wealth, silver and gold, are not things of the devil as some people imagine. . . . Because all money belongs to the believer and to the unbeliever not an obol. . . . Only employ it properly and there is no blame in money. . .. One can justify himself through money [if hle used it for charity]" (8.214).

Page 47

Second, the Fathers regarded money in the form of precious metals (Basil 1972b, vol. 3, 5-10, letter 88; Chrysostom 1962-75, vol. 55, 155A; vol. 63, 138E). ${ }^{9}$ They stressed that the true role of money is that of a medium of transaction, and a measure of value (Basil 1972b, vol. 3, 5-10, letter 88; 1976, vol. 11, 55A, 59E; Chrysostom 1962-75, vol. 6, 372A; vol. 54, 119B; vol. 73, homily 46.4; vol. 74, homily 59.4; vol. 76, homily 11.3). ${ }^{10}$ They attacked the use of money as a means of storing value and wealth, emphasizing that such a function of money is not a natural and useful one. On the contrary, they regarded this function as one of the causes producing the maldistribution of wealth. Chrysostom argued that the etymology of the Greek word chremata (money) is based on the notion of use, and that money must circulate and not be idly hoarded ${ }^{11}$ "Furthermore that is why it is called chremata so that it can be used in the service of one's fellow beings, not to be hoarded, unused. . . . You acquire money not to hide it but to share it" (vol. 72, homily 17.3). "That is why it is called 'chremata' to be used where it is needed and not buried in the ground" (vol. 66, 508E; see also vol. 67, 634A).

It is obvious that the Fathers have turned against the function of money as a means of storing value; while they considered that such a function diminishes the amount of money destined for almsgiving, they have implicitly recognized that it reduces the quantity of money in circulation and decreases economic transactions and demand.

Third, the existence of usury was another cause of unequal distribution. Early in the third century, Clement of Alexandria (1956d, B, 18) and other Fathers turned against the existence of usury, following the teachings of the New Testament. The same position again usury, justified on religious grounds, was also taken during the first half of the fourth century A.D. (see Cyril of Jerusalem 1969, 4.130); expanded

9. Chrysostom mentioned that there was a time when people did not use precious metals as money, a function which took place with the development of the human race (1962-75, vol. 75, homily 74.3$)$.

10. In a representative statement Chrysostom wrote that "price is considered as an economic exchange. We often sell our slaves and receive gold or silver in exchange 
for the sale" (1962-75, vol. 55, 155A). Basil, considering money to have its own exchange value, noticed that its value is directly related to the volume of goods that is exchanged. Where the quantity of necessary goods is very low compared with the demand for them, as happens in the case of famine, the price of these goods is very high and the value of money very low (1976, vol. 11,8, 66B-C).

11. Clement of Alexandria (1956, 357-58, 25-40) developed a similar argument regarding the use of money.

Page 48

during the last decades of the century, the doctrine against usury was additionally based on economic grounds derived from arguments developed by the Greek philosophers. Basil was opposed to the existence of usury-as was his brother Gregory of Nyssa (Houmanidis [1972] 1979, 42) - treating it as an effect of an unnatural function of money [Basil 1972b, 4:10-15, letter 109). Justifying his objection on the sterility of money thesis - a similar justification that had been developed by Plato and Aristotle (see Karayiannis 1990, 26) - Basil argued that "copper and gold and the unproductive are unnaturally generated and increased through interest" (1976, vol. 11, 66A). Gregory of Nazian-zus developed the same argument against the existence of usury: "Another man has poisoned the earth through interest and usury, by collecting income from what he did not sow and reaping what he did not plant, cultivating ana exploiting not the land but the difficult position of those in need" (1977, vol. 5, 18.1-5, homily 16; emphasis added). ${ }^{12}$

Chrysostom was also hostile toward the existence of usury, because he regarded that by its function the poverty of the borrower and the wealth and the sin of the lender were both increased (1962-75, vol. 47, 413B). He emphasized that usury reinforced the unequal distribution of wealth and asked for its abolition, particularly for the loans destined for consumption purposes (vol. 9, 337C-D; vol. 64, 239B). ${ }^{13}$ By trying to persuade the citizens to abolish usury, he noted the visible risk of not paying back not only the interest but also the capital lent [vol. 67, 574E). In the end, he painted in dark colors the effects of usury: "nothing, truly nothing is more contemptible and cruel than interest. ... Without a doubt, interest . . traffics on the misfortune of others and turns the bad luck of others into your personal gain" (vol. 63, 82B-C).

However, Chrysostom was open-minded enough to recognize that some voices on behalf of the existence of usury might arise on the ground that someone is benefiting from another's capital—an argument put forward by some ancient Greek orators such as Isocrates and

12. Though usury was condemned by the Fathers, there were loans with a rate determined by the governnrient. The $r_{a}$ te of interest in those times was about 4-8 percent, while the Emperor Justinian did not permit interest of more than 12 percent (Rice [1967] 1972, 173).

13. For an excellent and thorough analysis on the position of Jews regarding interesttaking as developed in the Old Testament and the talmudic literature see Gordon (1987, 49-51) and Ohrenstein (1^70. 34-35; 1987, 72).

Page 49

Demosthenes (see Karayiannis 1992, 75). His reply to such voices is withdrawn by his religious beliefs in stating that if the loan was given without interest, the lender could earn the reward of God: "But then what are you advising us, one will ask. That I 
should give another the money I have collected on my own and that is useful to me, for his own use without asking for my profit? Forget all that. I have never maintained that, quite the contrary, I want you to profit a great deal, not some small and insignificant profit, but something much greater. That is, instead of money I want you to receive the interest heaven grants" (Chrysostom 1962-75, vol. 63, 83A).

Fourth, the unequal distribution of wealth is augmented by the condition of the labor class. The laborers, according to Chrysostom, who by their labor decrease the scarcity of goods, receive very low wages, and their employment is not secure. Chrysostom justified the necessity of work on economic and religious grounds derived from the Old and New Testaments. ${ }^{14}$ He argued that labor is necessary to diminish the scarcity of goods and to divert the people from sin (1962-75, vol. 35, 178D, 180B) - justification also developed by Clement of Alexandria (1956d, A, 1), and Saint Augustine, who noticed that human beings are faced with "the tediousness of indolence and the goad of necessity" (1954-56, 22.30). In addition, Chrysostom stressed that work strengthens the ethical situation of the individual, while idleness is a mark of both low ethical character and social estimation (1962-75, vol. 35, 175B, $178 \mathrm{~B}, 179 \mathrm{~B}-\mathrm{E})$. He concludes with the following regarding the ethical effects of work: "I wish every one to work. Because idleness teaches every evil" (vol. 65, 402E). "That is why God created us with the necessity for work, because by indolence everything is damaged" (vol. 78, Apostle, homily 35.3). "God tied the man to labour, not for the purpose of punishing or chastising, but for amendment and education" (Chrysostom 1842, 50).

Chrysostom developed some interesting arguments regarding the utility and the pains of labor. First, he mentioned that the work by itself produces direct utility to the laborer because it induces one to feel like a creator (1962-75, vol. 73, homily 36.2; vol. 16, 33E). But, he did recognize that work is bearing disutility to the worker through the pain of labor (vol. 58, 354B). However, Chrysostom does not relate

14. On the understanding of work in the Old and New Testaments see Gordon (1987, 63-64).

Page 50

the direct and indirect (through the wage earned) utility of labor with its disutility because of pain, as the marginalists did centuries after him, in order to explain the economic behavior of laborers and to justify their fair reward.

Next, Chrysostom specifies that most people are laborers (including slaves), who get only a bare level of subsistence from their wages, while their employment is not continuous but periodical (1962-75, vol. 36, 249B-C; see also Basil 1972a, vol. 3, $3) .{ }^{15}$ Furthermore, he noted that there are many who are unable (too young, too old, disabled) to work and to receive wages (1962-75, vol. 37, 289C). On the other hand, he recognized that the immobility of labor between different employments causes a low wage rate. ${ }^{16}$ He justified this immobility on the grounds that because of the division of labor, the time consumed by the laborer in obtaining the experience and knowledge that is needed for a specific job is high (vol. 66, 508E-509A), and the laborer is assuming some additional risks in undertaking a new job (vol. 6, 406B-C)."

Fifth, the unequal distribution of land was an important source of the maldistribution of wealth. The feudal structure of agricultural production at that time (see Houmanidis 1990, 3-4; Stevens 1966, 115) was characterized by the absence of investment by landlords and the low wage level. Chrysostom, in a passage where he stigmatized the inhumanity of landlords (1962-75, vol. 67, 614A-C), stressed that this 
structure and function of agricultural production is the main cause for

15. Regarding the rate of wage, the only thing that is mentioned by Chrysostom is that [here exists a "fair" one (1962-75, vol. 67, 574D), but he did not elaborate on the factors that determine it or specify what this fair rate was.

16. In the Fathers' time the mobility of labor was very low, not only because of the rare employment opportunities but also because of the feudal organization of agricultural production and the paternalistic structure of the economy (see Houmanidis 1990, 4; Rice [1967] 1972, 237).

17. Regarding the division of labor, the Fathers developed various views. Chrysostom mentioned that poverty is providential and causes the increase of the division of labor, while iffluence decreases it (1962-75, vol. 31, 744A-B; see also Gordon 1989, 118). Basil noted that people were following different occupations in order to earn their living (1972b, vol. 3, 35-45, letter 94). On the other hand, Nemesius of Emessa developed a Platonic theory (see Karayiannis 1990, 18-19) for the consequences of the division of labor on the formation of society, arguing that as individuals have different inclinations they are engaged with different occupations (1968, 520-21). Thus, for individuals to fulfill their various needs, as they are not self-sufficient, a transaction activity emerged among them. Through this activity the city is established and the individuals share the benefits of economic transactions.

Page 51

(a) the low wage level in this production; (b) the high rate of land rent; and (c) the economic dependence of the artisans and small farmers (mainly through lending activities) on the landlords. ${ }^{18}$

\subsection{Economic Classes}

According to the Eastern Fathers, the existing maldistribution of wealth generated by the factors discussed above also led to distinct economic classes, and the consumption of luxury goods, which caused a decrease in the living standard of the poor. In response, they tried not only to reduce the size of the lower class, but also to eliminate the boundaries between the classes. Chrysostom explicitly recognized the tripartite economic class structure. He noticed that "the tenth part of citizens are rich, another tenth part are poor, they have nothing, and the rest of the citizens belong to the middle class" (1962-75, vol. 68, 658A). ${ }^{19}$ Moreover, he emphasized that the rich, possessing economic and political power, are able to and do abuse, depress, and exploit the weak and the poor in various ways (vol. 54, 121A; vol. 56, 205B-C; see also Vallianos 1979, 54-55).

The Fathers also discussed the economic condition of another class, of people: slaves. Though they did not start any crusade against this institution, they tried to persuade the masters to treat their slaves humanly, giving a religious explanation for the establishment of slavery. They considered (see Basil 1973, vol. 10, 20, 50-51; Chrysostom 1962-75, vol. 15, 782C-D; vol. 52, 659A, 662B, 665B) that though slavery is a situation contrary to the nature and the law of God, it was established as a punishment for individual sin and as a remedy for it. ${ }^{20}$ Basil, in the same passage (5051), also justifies slavery on the existing differences between the natural and spiritual abilities among indi-

18. Chrysostom considered that agriculture was the most useful and important produc- 
tion activity (1962-75, vol. 10, 348D-E). The same priority to agricultural production was also given by the ancient Greek philosophers (see Houmanidis [1972] 1979, 33 34; Karay-iannis 1988, 384; 1990, 9; 1992, 68-69). Besides, he stressed that the fertility of land had been offered by God and it could only through human labor be increased and not created (vol. 41, 36B, 44C; vol. 58, 354B).

19. Augustine also recognized the class structure of society $(1954-56,19.13)$ and mentioned that as some groups of people have different targets and means, the oppression of rich over poor emerged (2.2).

20. The same explanation for the existence of slavery was also given by Augustine (1954-56, 19.15; see also Viner 1978, 27).

Page 52

viduals, claiming that this institution embraces individuals who are inferior in nature and ability (see also Viner 1978, 28).

Chrysostom, on the other hand, distinguished between three kinds of slavery: (1) the slavery of women by men (1962-75, vol. 52, 659A); (2) the normal slavery of "brother from brother" (vol. 52, 660D); and (3) the slavery of lords (vol. 52, 661B). The first kind of slavery could be abolished under the commandments of Jesus and the Apostles. The consequences of the second could be eliminated-as Chrysostom (666A-B) and Gregory of Nyssa (Spentzas [1969] 1984, 118) stressed-if the slaves had virtue and patience, and the masters treated them humanly. Moreover, Chrysostom, in a statement from his "Homilies on 1 Corinthians," recommended "that Christians should provide an education $i_{n}$ a craft for their slaves, and then emancipate them" (Gordon 1989, H6; see also Christou 1975, 122-23). In another statement, wher he describes with nostalgia the early days of Christianity, Chrysosto $\mathrm{m}_{\mathrm{m}}$ mentions that in those days slavery had been abolished among Christians, and he wishes the same would take place in his time (1962-75, vol. 76, homily 11.3). As to the third kind of slavery, Chrysostom $c a \bigwedge_{s}$ it unnecessary, if individuals behave according to the teachings of the New Testament: "The Laws are the highest lord of all. . . But \% person who lives justly has no need of the law. . . And if there $j_{\mathrm{s}}$ no need of the law, then there is even less need of the aforementioned lord" (vol. 52, 662A).

\subsection{Luxury Consumption}

According to the Fathers, the consumption of luxury goods emerged because of human vanity and the unequal distribution of wealth, and they examined the subject extensively from an ethical and economic standpoint. Basil developed the following specific objections against luxury consumption. First, he considered the consumption of luxury goods as destined to fulfill only "imaginary and satanic" needs, and therefore to be shunned (1976, vol. 11, 52D-53B). Similarly, Gregory of Nazianzus stressed that luxury goods "are of those things which cheat and allure the ey $\ll \mathrm{j}_{\mathrm{s}}$ " (1977, vol. 5, 16.5-10, homily 14). ${ }^{21}$ Basil

21. Clement of Alexandria (I956a, 2.3) and Cyril of Jerusalem (1969, 4.118) stressed that the necessary needs, and $\mathrm{r}_{\mathrm{o}} \mathrm{t}$ the luxury ones, must be the measure for the acquisition of wealth. Augustine also turned against the accumulation of wealth in order to spend it on luxury goods $(1954-56,1.30)$; however, he did not approve of the way of thinking: "We praise wealth and love idleness" (5.11). For the opposition of the Western Fathers to the consumption of luxury goods, see Viner 1978, 21. 
sarcastically described the luxurious way of life and questioned the kind of needs that are fulfilled by silver beds and other ornaments (1976, vol. 11,7, 53D). He turned against conspicuous consumption by noting that luxury goods exist only to satisfy the vanity of the rich (56B).

Another reason for Basil's opposition to luxury consumption had to do with his distinction between productive and unproductive labor and arts, using the same ground as Smith did later on (Gordon 1989, 114). In his Hexaemeron, Basil distinguished the arts into "theoretical, practical, and productive," writing that "the purpose of the theoretical arts lies in the activity of the mind, for the practical arts it is the motion of the body itself which when it ceases, nothing remains, nor even for spectators, that is, there is no reason for dance and music but the activity itself which is also the highest aim of its own being. . . . When energy ceases in the productive arts, the work lies before us like the works of the construction art and architecture" (1.16).

On the same subject, Chrysostom emphasized that "nothing-nothing is worse than luxury" (1962-75, vol. 14, 719A), and noted the following deleterious ethical and economic effects produced by the consumption of luxury goods and services: (1) the consumption of luxury goods is but a sample of human vanity (vol. 44, 179A) expressed through conspicuous consumption; ${ }^{22}(2)$ the spending of money on immoral purposes, such as prostitution, is wrong, because immoral situations are reinforced in this way (vol. 73, homily 42.4); (3) the consumption of luxury goods decreases the goods disposable for charity (vol. 75, homily 82.4); and (4) the production of luxury goods not only corrupts the producers but also wastes the factors of production, above all, labor (vol. 66, 509D, 511A-C).

From the above analysis, it is evident that the Fathers were not hostile to, and did not prohibit, the possession of wealth, but rather offered advice for its proper use and accumulation. However, they did not recognize two effects of accumulation that could improve the living standard of the poor: the consumption and the investment effects. The Fathers did not realize that luxury consumption by the rich or idle

22. "We build houses that we may have a habitation; not that we may make an ambitious display. What is beyond our wants, is superfluous and useless" (Chrysostom 1842, 28B).

Page 54

consumers could improve the economic status of the poor because the rate of employment and wage would be increased. ${ }^{23}$ On the other hand, they did not relate the positive economic effects of investment activity accruing to the whole economy because in those times this activity did not characterize the rich, while entrepreneurial activity was not noticed by them (Gordon 1989, 119-20).

\section{Redistribution of Wealth}

In the time of the Fathers, poverty, as Constantelos put it, "was an endemic phenomenon" $(1981,83)$. They tried not only to explain this situation of poverty-as discussed previously_ but also to suggest definite measures for its diminution, if not for its abolition. According to the Fathers, poverty and the unequal distribution of wealth could be decreased endogenously, when altruistic motives are more than or 
equal in strength to those of self-interest. Where the altruistic motive is expressed by almsgiving, then a redistribution of wealth could take place. Also, they considered that the unequal distribution of wealth could be exogenously decreased by a proper taxation system levied by the administration of the empire.

\subsection{Altruistic Behavior and Almsgiving}

During the second half of the fourth century A.D., religious thinkers seemed to recognize that praying to God for the securing of food was not enough, and turned to humanity, and particularly to human feelings, for the securing of "bread" for all. This appeal to altruism was tempered by the Fathers' admission of the difficulty of an absolute transformation of motives within a given person. They recognized that a person driven by self-interest to accumulate wealth, namely, the rich, as Jesus had emphasized (see Matt. 19:23-26; Mark 10:24-26; Luke 18:24-27), is unlikely to have an absolute change in motive and to become altruistic in order to share that wealth. To solve this problem, the Fathers tried exhortations, and sometimes indirect threats regarding life after death, to persuade the rich to increase their altruistic

23. As Viner rightly comments, "No Father seems to have recognized the possibility that income or property in excess of current need might help the poor more if used productively to provide them with cheap necessaries or with remunerative employment than if distributed as alms" $(1978,23)$.

Page 55

behavior. ${ }^{24}$ In order to persuade people to express altruism through almsgiving, the Fathers promised them that their sins would be forgiven and that they would receive eternal life. Thus, it seems that they introduced not "strong," but "weak altruism," or "enlightened self-interest" as it has been defined by Simon: "We speak of weak altruism when an individual sacrifices fitness in the short run but receives indirect long-run rewards that more than compensate for the immediate sacrifice" $(1983,58)$.

Chrysostom and the other Fathers admitted that human beings are partly directed in their lives by altruism, which is teachable and not genetic or natural. ${ }^{25}$ For the Fathers, this altruistic motive could be increased and reach perfection through Christian teachings. Thus, their writings tried to persuade people to increase their altruistic, and decrease their selfish, behavior. To accomplish this the Fathers used ethical, religious, and economic ideas and beliefs. Touching briefly on their first approaches to the persuasion of people, the following analysis focuses on the last approach, which is based on well-developed and - for noneconomist theologians-consistent arguments. Regarding charity, Basil is explicit not only in his words but also in his personal activity in the establishment of the philanthropic institution Basileias. ${ }^{26} \mathrm{He}$ emphasized that wealth had been given to the rich by God in order to distribute it to the poor (1976, vol. 11, 44C) — a similar argument also put forward by Gregory of Nazianzus in his homily "On Love Towards the Poor" (see Vallianos 1979, 55).

Chrysostom, who also actively tried to help the underprivileged (Constantelos $1968,68,71)$, argued that the unequal distribution of wealth could be eliminated only when the altruistic motive-which is the cornerstone of Christianity (1962-75, vol. $52,690 \mathrm{E}$ ) and is expressed by charity, "the heart of virtue" (vol. 66, 492A)—functions

24. The statement of Clement of Alexandria is the most representative of these exhortations: "Oh supreme benevolence! Not as a teacher to pupils, not as a master to 
his slaves, not as a God to men, but as a kind father admonishes his son" (1956b, 9, $18,2)$.

25. Recently, the biologist Dawkins developed the idea that altruistic behavior is teachable to human beings, who are selfish by nature $(1976,26-27,86,93,179,270$, 377-78).

26. For this philanthropic institution see Constantelos 1968, 154-55; 1981, 81; Spentzas [1969] 1984, 116. Basil, in his "Utter on the Consequences of Famine and Drought" (1976, vol. 11, 62C-63B, 64A-E, letter 8), describes the misery of the poor in order to persuade his fellow citizens to offer some of their surplus products. Also, in another letter (1972b, vol. 2, 31), he recounted his own activities for the decrease of misery during that time of famine. As Constantelos comments on Basil's attitude for the elimination of poverty, "The Greek concept of philanthropia and the Christian understanding of agape blended into a powerful ethic which determined his moral philosophy and social involvement" $(1981,82)$.

Page 56

strongly enough inside the rich (vol. 63, 69C). He used statistical data (vol. 69, 810A; vol. 76, homily 11.3) to prove that in the large cities such as Antioch and Constantinople, the rich had sufficient products and money at hand to meet the needs of the poor through almsgiving, if they wished. ${ }^{27}$

Chrysostom also argued that wealth accumulated by fair and/or unfair actions, must be distributed for the following reasons. One, this distribution does not produce any trouble for the rich: "tell me where is the strain when you enjoy what you have and spend the excess on the needs of the poor" (1962-75, vol. 37, 267D). Two, through almsgiving all the sins and injustice that the rich have committed in order to accumulate wealth are pardoned. He reasoned that "the rich man is, as it were, a receiver of goods which are destined to be dispensed to the poor-to those of his fellow-servants who are in want. If he then should spend upon himself more than he really needs, he will pay hereafter a heavy penalty. For the things he has are not his own, but are the things of his fellow-servants" (Chrysostom 1869, 51; see also 196275, vol. 37, 266E-267E, 279A; vol. 46, 342E; vol. 68, 658E-659A, 728E-C, 729B-C). Chrysostom decreed that those accumulating wealth through unfair actions would be forgiven only if they gave their wealth to charity and abandoned those actions (vol. 37, 288E-289A; vol. 67, 536D, 537B; vol. 75, homily 73.3) - the same argument was also put forward by Augustine (1954-56, 21.27).

Chrysostom defined the economic character of almsgiving by the following statements: "If we have more than is necessary, we must share it with those who need" (1962-75, vol. 35, 186D; see also vol. 10, 242B; vol. 44, 179C; vol. 47, 380C). "That is why you have money, to free others from poverty, not to exploit poverty" (vol. 67, 573C). "Your surplus shall make up for the lack of others" (vol. 44, 180A). "Give the poor the benefit of your goods and be a good manager of what God has given you" (vol. 68, 658E-659A). "I do not want to stop you from enjoying your wealth, but from covetousness and rapacity. I do not call on you to get rid of all your money, but to give according to your means to those in need" (Attwater 1959, 67).

Chrysostom, to use modern terminology, seems to have considered that the welfare function of individuals had a positive relationship with

27. Viner writes the following regarding Chrysostom's statistical approach: "One would not expect to find the Fathers dealing with charity in statistical terms. One of 
the Fathers, St. John Chrysostom, did deal with it, however, in a surprisingly modernsounding way" 1978, 25).

the amount of almsgiving, and that charity is a factor included in the general welfare function of society.

The Fathers, having proposed almsgiving on the basis of pity, moral justice, and redemption from sin (Viner 1978, 20), also sought to put forth some regulations regarding discrimination in almsgiving. Chrysostom argued that there must be no discrimination in discerning charity (Gordon 1989, 116). He mentioned that if someone is poor through idleness, charity must still be given, and after that we must try to convince the person that such behavior is not consistent with religious and economic ethics (1962-75, vol. 16, 30D; vol. 37, 276D-277A; vol. 65, 403A). However, in another case, he condemned the beggars who are able to work and choose not to (vol. 37, 267B). Moreover, Gregory of Nazianzus was in favor of indiscriminate almsgiving (1977, vol. 11,6.15-20, homily 14): "Let us give our possessions to the poor, in order to be rich with divine goods" (22.5-10).

On the other hand, Basil is more skeptical regarding indiscriminate almsgiving. ${ }^{28}$ Referring to the advice of another bishop, Basil noted that the bishop "added that it was not necessary for anyone to take upon himself the distribution of his goods, but only to commit this task to him to whom the management of the alms of the poor had been entrusted. ... He said that experience was necessary for distinguishing between the man who is truly in need and the man who begs through avarice" ([1926] 1961, vol. 4, 3, letter 150). Obviously, Basil questioned indiscriminate almsgiving because he wanted to persuade the rich to give their surplus to an institution (the church), which could distribute it more properly than they could individually.

From this analysis, the Fathers of the Eastern church, and especially Basil the Great and John Chrysostom, considered that the economic actions of individuals must be carried out in relation to charity. They did not seem to accept the separation between economic action and charity, or to use Knight's words, "the business-versuscharity-dualism," which according to him ([1939] 1982, 71), we may "call the second axiom or principle of liberalism." On the contrary, Basil and Chrysostom believed that all economic actions must be accompanied by charity and fairness, and were skeptical of the possibility of the rich accumulating great wealth only through fair economic actions and by their own labor.

28. Some of the Western Fathers also advocated discriminate almsgiving (see Viner 1978, 24).

Page 58

\subsection{Taxation}

The Fathers, though they did not question the purpose and the function of the authority of government (i.e., the emperor), emphasized that some of its actions could decrease the inequality of distribution. In particular, they asserted that through a change in the taxation system the situation of the poor could be improved. Chrysostom was against the equal taxation of rich and poor, advocating a proportional one (1962-75, vol. 11,119C). On the other hand, Basil, observing the heavy taxation 
burden upon the poor, proposed some interesting measures for the reconstruction of the taxation system in order to relieve their burden: (1) the taxation of the farmers, artisans, shopkeepers, and craftsmen had to be reduced if they were to produce the same and not fewer products (1972b, vol. 4, 10-12, letter 110). The same advice was also given by Gregory of Nazianzus (1977, vol. 5, 9.1-5, homily 18); (2) the abolition of the quadruple charge on late taxes (Basil 1972b, vol. 1, 5-10, letter 21); (3) the abolition of the arbitrary taxes levied from the tax collectors (5-10); and (4) the exemption from taxes of all the charity houses (vol. 4, letter 142). Another measure for the remedy of poverty suggested by Basil is related to the effects of the function of the "philanthropic" institutes.

And whom do we wrong when we build hospices for strangers, for those who visit us while on a journey, for those who require some care because of sickness, and when we extend to the latter the necessary comforts, such as nurses, physicians, beasts for traveling and attendants? There must also be occupations to go with these men, both those that are necessary for gaining a livelihood, and also such as have been discovered for a decorous manner of living. ([1926] 1961, vol. 3, 33-45, letter 94; emphasis added).

\section{Justifications for the Redistribution of Wealth}

In addition to the mentioned ethical and religious justifications for almsgiving, the Fathers also considered some economic ones related to the institution of property and the diminishing utility of goods. They questioned the origin and the purpose of the institution of property, while at the same time trying to prove that the function of almsgiving is compatible with the economic interest of individuals, because the

Page 59

utility derived by the consumption of goods and wealth is a diminishing one. The following section analyzes the views of the Fathers regarding these two economic justifications.

\subsection{The Institution of Property}

The Fathers based many of their arguments for the redistribution of wealth upon the origin of the institution of property and its consequences on the general welfare. Chrysostom maintained that the general welfare of society is a positive function of peace, of the quantity of production, and of the relatively equal distribution of products (1962-75, vol. 58, 341B). He and Basil turned primarily to the third factor as the most crucial one in determining the rate of welfare, and not to the second; they thought that the scarcity problem was mainly caused by the existing unequal distribution of production, not by its low rate.

The Fathers considered the most perfect system to be the common ownership of all goods produced. They justified this system under the following principles: (1) the common ownership of all the earth's goods; (2) the brotherhood of individuals; and (3) the Lord's commandment of love (Matt. 25:34-36; Luke 6:27-30; John 13:34-36).

Regarding the first principle, Chrysostom remarked, "Can't you see that God gave us all things in common? Because though he permitted the existence of those poor in money he did this for the sake of those who acquire wealth, so that they can wash away their sins by means of charity to the poor" (1962-75, vol. 75, homily 77.4). He goes on to say that "God wants us to have everything in common, both bodies and 
money, both the poor and the greedy" (vol. 64, 237C).

Basil also mentioned that God had given the goods to be distributed equally among individuals. The rich are obliged - according to the teachings of Jesus - to voluntarily distribute through charity their sur-plus to the poor $\left(1976\right.$, vol. 11, 96C) ${ }^{29}$ However, Basil, observing that such an activity was not followed by the rich, commented, "So you i.e., the rich] are not greedy? So you are not a depriver? Since what you received for common sharing you made into your own? ... The

29. The same idea was also stressed by Clement of Alexandria, who reasoned that "God has given us the right to use [our possessions], but only within the limits of necessity; and he has ordained that this use be in common. It is therefore wrong that one should be in luxury while the many are in distress" (Gordon 1975, 95-96).

Page 60

bread you possess was for a person who is hungry. The clothes you have in your chests are for an unclothed person. . . The money you bury in the ground is for those who need" (50B-C). Regarding the principle of brotherhood and common property of goods, Chrysostom wrote that "the world is meant to be like a household, wherein all the servants receive equal allowances, for all men are equal, since they are brothers" (Attwater 1959, 64). ${ }^{30}$

For Basil, when individuals obey the Lord's commandment to love, that is, to love one's neighbor as oneself (Matt. 12:39-40; John 13:34-35), everybody will get what they really want and not more than that, and thus the distribution of products could not be characterized by extreme inequality. ${ }^{31}$ Moreover, he insisted that in the case of famine, goods must be under common ownership (1976, vol. 11,8, 71 A). Chrysostom, using the same argument of worldwide love on behalf of voluntary common ownership, asked whether "the lack of property came from love or love from the lack of property? I believe that the lack of property came from love" (1962-75, vol. 76, 11.1). He then developed some positive social and economic effects caused by the common ownership of the produced goods. Specifically, he argued that by this institution harmony and peace prevail in the society; conversely, "wherever the custom of what's mine and what's yours rules there one finds all kinds of rivalry and every cause for altercation" (vol. 46, 336A; see also vol. 13, 92A-B; vol. 64, 264C; vol. 76, 13.3). Moreover, he regarded that by this institution poverty could be eliminated while the living expenses could be decreased, as happened in Jerusalem in the early days of Christianity and in the monastery circles.

By selling their possessions they [i.e., early Christians in Jerusalem] did not come to be in need ... it is the living separately that is expensive and causes poverty. ... The dwellers in the monaster-

30. The principle of brotherhood as a justification for common property has also been used by Plato (see Karayiannis 1990, 31). However, Plato's principle has a philosophical basis rather than a religious one, unlike Chrysostom's, and its extent is narrow (under this principle are included only the citizens of a city-state), not worldwide as is Chrysostom's.

31. Chrysostom noticed that in the monastic circles the existence of common ownership had halted the conflicts among the monks (1962-75, vol. 13, 94A). Basil developed the following economic norms to be practiced by the monks in order to establish a peaceful and Christian society: (1) the monks must do what has been ordered (1972b, 1:28, letter 22); (2) the monks must consume only the necessary 
goods (20-21); and (3) the monks must share common ownership (13).

ies live just as the faithful did then: now did ever any of these die of hunger? Was ever any of them not provided for with plenty of everything? Now it seems, people are more afraid of this than of falling into a boundless bottomless deep." (Gordon $1989,117-18)^{32}$

However, it is a different thing if someone expresses a preference for something (i.e., an economic system as Chrysostom does for communal ownership of goods produced), than to establish it theoretically and use it to convince others to accept it. ${ }^{33}$ Chrysostom was not a propagandist on behalf of communism, though he favored this system on the additional ground, as Gordon states $(1991,6)$, that this would eliminate "the spiritual dangers to individuals associated with the private possession of property." Nevertheless, Chrysostom was well aware that by the institution of property in the means of production, work effort and responsibility are increased: "in this respect the shepherd differs from the salaried worker in that he [i.e., the salaried worker] is thinking of his own personal salvation at all times, neglecting the sheep, while the other [i.e, the shepherd] is always concerned with his sheep's salvation, neglecting his own" (1962-75, vol. 74, homily 60.1). Besides, he did not denounce the accumulation and ownership of wealth-as seen in section 1.2-if it is accumulated by fair actions and is used rationally, for necessary goods and almsgiving.

\subsection{Diminishing Utility}

In addition to the moral defense of redistribution of wealth through almsgiving the Fathers, and specifically Chrysostom, justified it on the grounds of a psychological and economic phenomenon. Chrysostom emphasized that the value of a good is subjectively estimated. He recognized the so-called "paradox of diamonds and water" in the theory

32. Basil commented: "Whomever loves his neighbor as he loves himself should not have more than his neighbor does" (1976, vol. 11, 52B); furthermore, "Since the welfare and the needs of the poor are paid for by the rich each one receiving a little for his necessary maintenance and care, then everyone will share their goods and spend them on themselves. So if you love your neighbor as yourself, you should not have more than he does" $(7,52 \mathrm{~B})$.

33. The indecisiveness of Chrysostom in proposing the establishment of a new institution, as the one of common property, could be explained if we consider that he was living in the "priestly stage" of Christianity, and according to Boulding's observation, at this stage religion "becomes a conservative force making for the persistence of established routines" (Boulding [1968] 1970, 180).

Page 62

of value, by stating that though silver is more useful than gold, the iecond has more value than the first, because "the value of a given hing does not depend on its nature but on our state of mind" (1962-75, vol. 10, 241A).

Chrysostom-using the dictum "It was not given us at first to live or the sake of eating, but to eat for the sake of living" (1962-75, vol. 14, 719D)—claimed that the utility of a good diminishes in terms of ts quantity, while it increases in terms of the pressing (or not pressing) needs that the good satisfies. "The pleasure [from food] is 
created by appetite. And appetite is not created by satiation and abundance but by lack and scarcity" (vol. 40, 70). "Pleasure occurs when it is preceded by desire and followed by enjoyment; if there is no enjoyment then here is no desire to be found and pleasure disappears" (vol. 25, 453D). "For we have a great desire for what we are deprived of be-cause desire arises from want. Because where there is satiation, there can be no desire" (vol. 68, 772C). ${ }^{34}$

Chrysostom, distinguishing between necessary and luxury goods, considered that the consumption of the first kind gives more utility to he consumers of low income, than the consumption of luxury goods to the consumers of high income. ${ }^{35} \mathrm{He}$ thought that the interpersonal comparison of utility could supply some useful conclusions in regard to the utility derived from the consumption of different goods (i.e., neccessary vs. luxury) by the different classes of people (i.e., poor vs. rich). He observed that the decrease in utility produced by the allotment of some goods by a poor person to almsgiving is much higher than that produced by a rich individual, who is supplying to almsgiving the same amount of goods (1962-75, vol. 31, 744D-745C). Thus, he concludes that if the two individuals must sacrifice the same utility he rich one must give to charity many more goods (vol. 10, 240E; vol. 25, 450B-C). In another statement, he noticed that the utility of money is also diminishing; a poor person finding a copper coin of

34. Chrysostom, viewing an interpersonal comparison of utility, mentioned that the poor rceive much more utility from poor food than the rich from luxury food, as the latter's con-sumption schedule is nearer to the saturation point (1962-75, vol. 16, 31CE). The same ar-gument was also developed by Titus of Bostra $(1959,2.8)$.

35. Nemesius of Emessa (1968, 680), by distinguishing between necessary and luxury goods, also argued that the consumption of the first gives more utility if the individual is be-having according to the ethical and religious teachings.

Page 63

small value derives much more utility than a rich person who finds a gold coin of much more value (vol. 75, homily 81.3) — an argument similar to one put forward by Marshall. ${ }^{36}$

Chrysostom, in reaching his conclusion for the interpersonal comparison of utility, had presupposed the following: (1) "the measure for pleasure is the same for the rich as for the poor" (1962-75, vol. 31, 745A); (2) there is saturation of consumption and thus diminishing utility, namely "because of the fact that the rich eat without feeling hungry, . . . and sleep without feeling tired, usually means that the pleasure from all these functions is lost" (vol. 31, 745C); and (3) the urgency for the fulfillment of a material need is the determinant factor for the utility of goods and not its characteristics and quality. ${ }^{37}$ From this analysis it seems that Chrysostom emphasized, as the measure of value of a good, the utility derived by its use rather than its cost of production. He also stated that when use value is decreased, the same also happens to exchange value, that is, the price of the good: "The sale of something at a reduced price shows the baseness of its value" (vol. 55, 154E).

\section{Conclusions}

From the previous analysis it is obvious that the Fathers of the Eastern church during the fourth century A.D. (particularly its second half) developed their ethical and social analysis from their religious beliefs and the ethical and philosophical 
teachings of the ancient Greek philosophers. Unwilling to be blind followers of the Scriptures, they combined the ethical and religious teachings of their ancestors with their own experience in order to justify their arguments and exhortations regarding economic and social matters. By considering the actual eco-

36. "a shilling is the measure of less pleasure, or satisfaction of any kind, to a rich manthan a poor one... An increase by (say) a quarter of the wages of the poorer class of bone fide workers adds more to the sum total of happiness than an increase by a quarter of the incomes of an equal number of any other class (Marshall [1890] 1959, 16,597).

37. Crysostom commented that "it is not the nature of those things [i.e. food, water, e.t.c.] but the need to use them that makes each thing pleasurable to us. And one does not take as much delight fromm drinking sweet and fragrant wine as being thirsty and drinking water" (1962-75, vol. 31, 745C; see also vol. 34, 112B). "Oftentimes have many of the poor, when wearied, and distressed, and parched with thirst, partaken of such streams even with such pleasure as I have said. But the rich, whilst drinking that is sweet, and has the odour of flowers, and every perfection that wine can have, experience no such enjoyment" (Crysostom 1842, 49).

Page 64

nomic activity around them, the Fathers' thinking was more than a simple restatement of the ethical exhortations related to the social activity of individuals as stated in the Old and New Testaments.

Their views regarding the matters of the "present life" downplayed the value of material achievements and elevated the ethical and spiri-tual values of life. In doing so, the Fathers advocated the marriage of religious ethics and economics on behalf of social justice. This ap-proach is evident from their attempt to solve the problem of unequal distribution of wealth and poverty. Regarding this problem, they considered that it was an artificial one, produced by the economic behav-or and activity of individuals and the structure and function of the economy. In their view, this unequal distribution of wealth led to the distinction of economic classes of society and the emergence of luxury consumption alongside poverty. The remedy for such a situation, the Fathers emphasized, was in the hands of individuals and the adminis-trators of the empire. Such a remedy was justified by the Fathers from the economic point of view, on the grounds that the institution of property is questionable, and that the utility derived by the consumption of goods and the accumulation of wealth is diminishing. In speaking for redistributive justice, the Fathers developed a theory that would produce an economically fair society only when the altruistic motive, which is expressed by almsgiving, or the voluntary sharing of goods, could be maximized.

\section{References}

Adeney, W. F. [1908] 1965. The Greek and Eastern Churches. Clifton, N.J.: Reference Book.

Attwater, D. 1959. St. John Chrysostom-Pastor and Preacher. London: Harvill.

Augustine, Saint. 1954-56. De Civitate Dei, vols. 1 and 2, Greek translation by A. Dalezios. Athens.

Basil the Great. [1926] 1961. Saint Basil-The Utters. Translated by R. Deferrari. Loeb Classical Library. 
1972a. Hexaemeron (in Greek). Thessaloniki: Gregory Palamas.

Organization.

1972b. The Letters (in Greek), vols. 1-8. Athens: Greek Publishing

1973. On the Holy Spirit (in Greek). Athens: Editions of Useful Books.

1976. Homilies (in Greek). Athens: Editions of Useful Books.

Boulding, K. [1968] 1970. Beyond Economics-Essays on Society, Religion, and Ethics. Ann Arbor: University of Michigan Press.

Page 65

Christou, P. 1975. Theological Studies (in Greek). Thessaloniki: Patriarchal Institute of Patristic Texts.

Chrysostom, Saint John. 1842. The Homilies of St. John Chrysostom. In On the Statues, English translation. Oxford: J. H. Parker.

- 1869. Four Discourses of Chrysostom. In The Rich Man and Lazarus, English translation by F. Alien. London: Longmans, Green, Reader, and Dyer.

. 1962-75. The Works of St. Chrysostom (in Greek). Vols. 1-71, Athens:

Greek Publishing Organization. Vols. 72-79, Athens: Editions of Useful Books.

Clement of Alexandria. 1956a. Paedagogus (in Greek). Athens: Apostolic Deacony of the Church of Greece.

Church of Greece.

. 1956b. Protrepticus (in Greek). Athens: Apostolic Deacony of the

- 1956c. The Rich Man's Salvation (in Greek). Athens: Apostolic

Deacony of the Church of Greece.

. 1956d. Stromateis, A, B (in Greek). Athens: Apostolic Deacony of the

Church of Greece. Constantelos, D. 1968. Byzantine Philanthropy and Social Welfare. New Jersey:

Rutgers University Press.

— 1981. Basil the Great's Social Thought and Involvement. Greek Orthodox Theological Review 26.1-2:81-86.

Cyril of Jerusalem. 1969. Catechisms (in Greek). Athens: Apostolic Deacony of the Church of Greece.

Dawkins, R. 1976. The Selfish Gene. Greek translation by L. Margaritis and A. Tsoukaladakes. Athens: Katoptro.

Geanakoplos, D. 1980. St. Basil, Christian Humanist of the Three Hierarchs and Patron Saint of Greek Letters. Greek Orthodox Theological Review 25.1:94-102.

Gordon, B. 1975. Economic Analysis before Adam Smith-Hesiod to Lessius. London: Macmillan.

— 1987. Biblical and Early Judeo-Christian Thought: Genesis to Augustine. In Pre-Classical Economic Thought-From the Greeks to the Scottish Enlightenment, edited by S. Todd Lowry. Boston: Kluwer.

1989. The Problem of Scarcity and the Christian Fathers: John Chrysostom and Some Contemporaries. Studio Patristica 22:108-20.

. 1991. Rich, Poor, and Slave in the Socioeconomic Thought of the Later Church Fathers. Paper presented at the Sixth World Congress of Social Economics, Omaha, August.

Gregory of Nazianzus. 1977. Ethical Homilies (in Greek). Thessaloniki: Gregory Palamas.

Houmanidis, L. Th. [1972] 1979. History of Economic Theories (in Greek), $2 \mathrm{~d}$ ed. Athens: Papazisis. 
1990. Again on the Question of Feudalism in Byzantium. Archives of Economic History 1.1:1-22.

Page 66

Karayiannis, A. D. 1988. Democritus on Ethics and Economics. Rivista Internationale di Scienze Economiche e Commercialli 35.4-5:369—91.

. 1990. The Platonic Ethico-Economic Structure of Society. Quaderni di Storia dell' Economia Politico 8.1:3-45.

. 1992. Entrepreneurship in Classical Greek Literature. South African

Journal of Economics 60.1:67-93. Knight, F. [1939] 1982. Ethics and Economic

Reform. In Freedom and Reform.

Indianapolis: Liberty.

Marshall, A. [1890] 1959. Principles of Economics, 8th ed. London: Macmillan.

Nemesius of Emessa. 1968. De Natura Hominis (in Greek). Athens: Apostolic

Deacony of the Church of Greece. New Testament (in Greek). 1973. Athens:

Apostolic Deacony of the Church of

Greece. Ohrenstein, R. 1970. Economic Aspects of Organized Religion in Perspective:

The Early Phase. Nassau Review (spring): 27-43.

- 1987. Some Socioeconomic Aspects of Judaic Thought. In Pre-

Classical Economic Thought-From the Greeks to the Scottish Enlightenment, edited by S. Todd Lowry. Boston: Kluwer.

Rice, T. T. [1967] 1972. Everyday Life in Byzantium. Greek translation by F. Floras. Athens: Papadimas.

Simon, H. 1983. Reason in Human Affairs. Oxford: Basil Blackwell.

Spentzas, S. [1969] 1984. An Investigation of Public Economics of the Byzantine State (in Greek), 2d ed. Athens.

Stevens, C. E. 1966. Agricultural and Rural Life in the Later Roman Empire. In The Cambridge Economic History of Europe, edited by M. Postan. Cambridge: Cambridge University Press.

Titus of Bostra. 1959. Against Manichaeans (in Greek). Athens: Apostolic Deacony of the Church of Greece.

Vallianos, P. 1979. The Attitude of the Three Hierarchs towards Knowledge and Learning. Greek Orthodox Theological Review 24.1:43-57.

Viner, J. 1978. Religious Thought and Economic Society. HOPE 10.1: 9-192.

Page 67 